\title{
CBFA2T3 wt Allele
}

National Cancer Institute

\section{Source}

National Cancer Institute. CBFA2T3 wt Allele. NCI Thesaurus. Code C97446.

Human CBFA2T 3 wild-type allele is located in the vicinity of $16 q 24$ and is approximately $102 \mathrm{~kb}$ in length. This allele, which encodes protein CBFA2T3, is involved in the repression of transcription. A translocation $\mathrm{t}(16 ; 21)(\mathrm{q} 24 ; \mathrm{q} 22)$ of this gene and the RUNX1 gene is associated with acute myeloid leukemia. 